\title{
Formulation and Sensory Acceptance of Cereal-Bars Made with Almonds of chichá, sapucaia and gurguéia Nuts
}

\author{
Michelle Garcêz de Carvalho ${ }^{1}$, José Maria Correia da Costa ${ }^{1}$, Maria do Carmo Passos Rodrigues ${ }^{1}$, \\ Paulo Henrique Machado de Sousa ${ }^{1}$ and Edmar Clemente*,2
}

\author{
${ }^{I}$ Department of Food Technology, Federal University of Ceará, Av. Mister Hull, 2977, Campus do Pici - Zip Code: \\ 60356-000- Fortaleza-CE, Brazil \\ ${ }^{2}$ Laboratory of Food Biochemistry, State University of Maringá, Av. Colombo, 5790, Zip Code: 87020-900, Maringá - \\ PR, Brazil
}

\begin{abstract}
The new trends for consumption of healthy, innovative and practical food have led to the growth of cereal-bar market in recent years. In the native Brazilian flora, there are some species still unknown, which have high potential for nut market, such as chichá, sapucaia and gurguéia. The aim of the present study was to produce cereal bars from those nuts, supplemented with pineapple peel. Cereal-bars made with chichá, sapucaia and gurguéia nuts were prepared by using three formulations as follows: A, B and C, respectively, which differ according to the proportions of vegetal fat and pineapple peel powder used in the processing system. It was verified, by using the global appearance parameter, that among the different formulations tested, formulation B obtained the highest rate for the attribute 'acceptability'. Chichá and sapucaia cereal-bars were, in general, more accepted than gurguéia nut cereal-bar. It was observed that the use of almonds of chichá, sapucaia and gurguéia nuts, and pineapple peel is feasible to produce nutritional cereal-bars.
\end{abstract}

Keywords: Residue, almond, sensory evaluation, cereal bar.

\section{INTRODUCTION}

The new trend for consumption of healthy, innovative and practical food, which has occurred recently, has leaded the market of cereal-bars to a gradual growth. Cereal-bars are considered healthy type of food, because they are rich in fiber, however, poor in fat [1-3].

According to Brinnehl [4] the consumption of cereal-bars in Brazil in 2004 was in the range of 464 million units $(25 \mathrm{~g})$, with a growth of $32 \%$ in relation to 2003 . It is considered that in addition to this new lifestyle, such a growth is also due to the high markup, as industries invest each time more in new cereal-bar formulations [5].

Cereal-bars are made of processed cereal grains that can be incorporated with different ingredients, such as whole cereals, dehydrated or crystallized fruits, chestnuts, nuts, almonds, sugar, candies, chocolates, etc. [6]. These ingredients must be suitably combined to assure a mutual complementation or supplementation as far as flavor, texture and physical characteristics are concerned, particularly the point of balance of water activity [7].

In the Brazilian native flora there are some species, which are not widely known, but that represent a potential to the market of almonds/nuts especially in the Middle-north area of Brazil, constituted by the states of Piauí and Maranhão. Among them, there are species such as chichá (Sterculia striata St. Hill. Et Naud), sapucaia (Lecythis pisonis

*Address correspondence to this author at the Laboratory of Food Biochemistry, State University of Maringá, Av. Colombo, 5790, Zip Code: 87020900, Maringá - PR, Brazil; Tel: + 55443261 3659; Fax: + 55443261 8940; E-mail: eclemente@uem.br
Camb.) and gurguéia nuts (Dipteryx lacunifera Ducker), all known only by the natives or by local populations [8]. In addition to being a source of energy, carbohydrate, protein, fiber, unsaturated fat, vitamins and minerals, the almonds of these species have pleasant taste and they can be used in the domestic and international almond market.

Regarding Brazilian fruit production, Brazil is regarded as one of the largest world producers of fruit [9]. However, the volume of post-harvest fruit losses is very high, which shows clearly the relevance and the need for expansion and the search for new knowledge in relation to their use [10].

The residues generated from the fruit processing system, such as peel, seed and bagasse, may be used in human diet by means of appropriate techniques, thus avoiding the waste of materials that may be used, by aggregating value to them, and these material can have as bases some substrates, which do not have any commercial value [11]. As an example of using this raw material, is to use both, pineapple peel and pineapple core in formulations of cereal-bars, syrup (used in canned/tinned fruits), vinegar, jams and cookies; whereas сириаси almonds can be used for manufacturing products similar to chocolate and to cocoa powder [12-14].

Within this context, the aim of this study was to formulate and evaluate the acceptability of nine types of cereal bars made with almonds of chichá, sapucaia and gurguéia nuts, supplemented or complemented with pineapple peel.

\section{MATERIALS AND METHODOLOGY}

The almonds of chichá, sapucaia, and gurguéia nuts, used in this experiment, were obtained from plants growing in the state of Piauí. Pineapple peels were acquired from an 
industry located in the city of Fortaleza/CE. Ingredients such as, glucose syrup (Yoki Alimentos S/A, Paraná - Brazil); brown sugar (Celeiro Alimentos Naturais, Fortaleza - Brazil); hydrogenated vegetable fat (Colméia, by Vida Alimentos Ltda. São Paulo - Brazil); rice flakes (Harald - Indústria e Comércio de Cereais Ltda. Pelotas - Brazil), oat flakes (Celeiro Alimentos Naturais, Fortaleza - Brazil), almonds; salt (Norte SA Salineira Indústria e Comércio Norsal, Areia Branca, Brazil) and pineapple peel (Ki Polpa, Fortaleza Brazil) were used for the different bar formulations (A, B, C).

Almonds of chichá, sapucaia and gurguéia nuts were roasted in an industrial oven, at $150^{\circ} \mathrm{C}$, for 15 minutes. To obtain the pineapple peel powder, the peel was thawed at room temperature $\left(37 \pm 2^{\circ} \mathrm{C}\right)$ for 3 hours, washed with running water, cut and placed in a Petri dish of $9 \mathrm{~cm}$ diameter, in order to carry out dehydration, using a vacuum oven at $65^{\circ} \mathrm{C}$, for 17 hours. Both, the pineapple peel and the almonds were crushed and bottled in a clean glass, which was coated with aluminum foil (to reduce the entry of light) and then with PVC film (to reduce the entry of oxygen and moisture). With regard to the pineapple peel cooking process, the same procedure, such as thawing and washing, was performed. For every $100 \mathrm{~g}$ of pineapple peel, $250 \mathrm{~mL}$ of water and $1 \mathrm{~g}$ of brown sugar were added, followed by the cooking process, at $93^{\circ} \mathrm{C}$, for 1 hour. The final formulation of cereal bars is shown in Table $\mathbf{1}$.

Table 1. Final Formulation of Cereal Bars Made with Almonds of chichá, sapucaia and gurguéia Nut, with Addition of Pineapple Peel

\begin{tabular}{|c|c|c|c|}
\hline \multirow{2}{*}{ Ingredients } & \multicolumn{3}{|c|}{ Formulation (g/100g) } \\
\cline { 2 - 4 } & A & B & C \\
\hline \hline Syrup of agglutination & & & \\
\hline Syrup of glucose & 20 & 20 & 20 \\
\hline Brown sugar & 15 & 15 & 15 \\
\hline Hydrogenous vegetal fat & 5 & 4 & 3 \\
\hline Dry ingredients & & & \\
\hline Rice flakes & 14 & 14 & 14 \\
\hline Oat Flakes & 15 & 15 & 15 \\
\hline Almonds & 21 & 21 & 21 \\
\hline Pineapple peel powder & 4 & 5 & 6 \\
\hline Salt & 0,5 & 0,5 & 0,5 \\
\hline Cooked Pineapple peel & 5,5 & 5,5 & 5,5 \\
\hline
\end{tabular}

The dry ingredients (rice flakes, oat flakes, almonds, salt, pineapple peel powder and cooked pineapple peel) were mixed in a rectangular stainless steel container, and then heated in an industrial furnace (Bandeirantes brand) at $100^{\circ} \mathrm{C}$, for 15 minutes. Simultaneously, it was prepared binding syrup (made of glucose syrup, brown sugar, vegetable fat) in a stainless steel container. The syrup was obtained by mixing the ingredients and heating them, stirring in water bath for 10 minutes, until a soluble solid content, ranging from 86.0 to $89.0^{\circ}$ Brix was obtained. Following this process, the hot ingredients were stirred again for 5 minutes, to homogenize the mixture. Further, the mixture obtained was poured and distributed in a rectangular-shape stainless steel container. Subsequently, the mass was covered with butter paper and PVC film, left to rest for cooling, then it was cut into rectangular pieces (with approximately $12 \mathrm{~g}$ each unit), and packed into bioriented polypropylene metalized flexible packaging. Fig. (1) shows the flowchart of the preparation process of bars with almonds of chichá, sapucaia and gurguéia nut, complemented with pineapple peel.

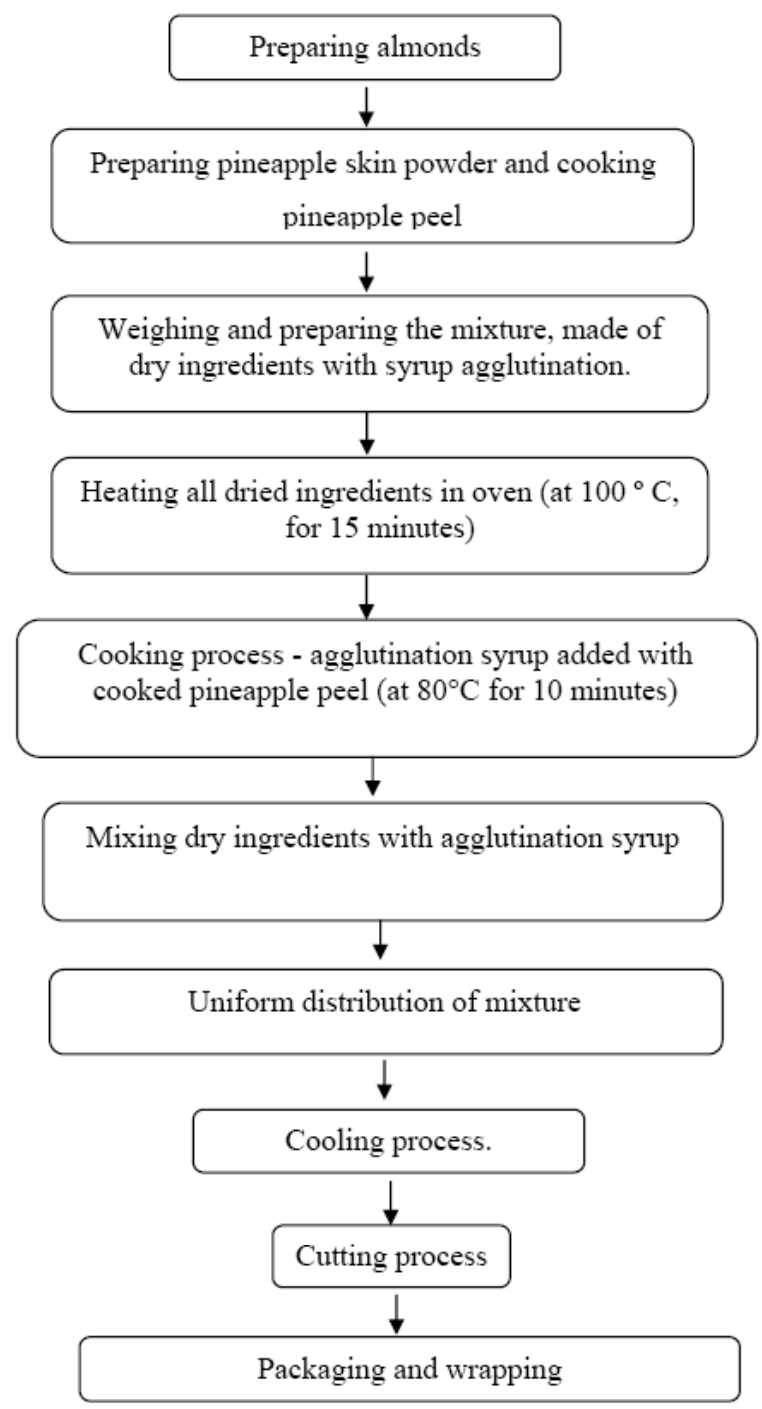

Fig. (1). Flowchart illustrating the preparation of bars made with almonds of chichá, sapucaia and gurguéia nut, complemented with pineapple peel.

Sensory tests were performed in laboratory, in individually lit booths, with 54 consumers (aged 18 to 35 years old) of both sexes (12 men and 42 women), in two sessions. Samples of $12 \mathrm{~g}$ were coded with three digits obeying a balanced complete block design. Sessions were carried out with samples varying the type of nut (chichá, sapucaia and gurguéia nut), plant and fat content of pineapple peel powder, respectively, $4 \mathrm{~g} / 100 \mathrm{~g}$ and $5.0 \mathrm{~g} / 100 \mathrm{~g}$ (formulation A), $4 \mathrm{~g} / 100 \mathrm{~g}$ and $5 \mathrm{~g} / 100 \mathrm{~g}$ (formulation $\mathrm{B}$ ) and $3 \mathrm{~g} / 100 \mathrm{~g}$ and 
Table 2. Averages marks awarded by Consumers/Assessors, in Relation to Sensory Acceptance of Bars Made with Almonds of chichá, Complemented with Pineapple Peel

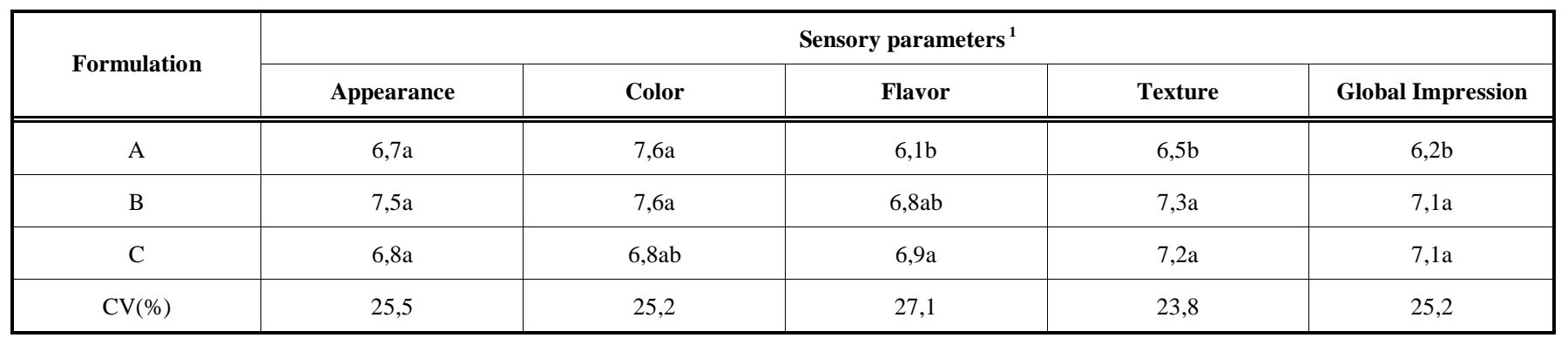

${ }^{1}$ Averages and coefficient variation. ${ }^{1}$ Averages with the same letter in the same column do not differ among them, by Tukey test at $5 \%$ significance.

Formulation A: with addition of $5 \mathrm{~g}$ of hydrogenated vegetable fat and $4 \mathrm{~g}$ of pineapple peel powder. Formulation B: with addition of $4 \mathrm{~g}$ of hydrogenated vegetable fat, and 5 grams of pineapple peel powder. Formulation $\mathrm{C}$ : with addition of $3 \mathrm{~g}$ of hydrogenated vegetable fat, and 6 grams of pineapple peel powder.

$6 \mathrm{~g} / 100 \mathrm{~g}$ (formulation $\mathrm{C}$ ). The cereal bars were evaluated by means of acceptance tests, using unstructured hedonic scale of nine points, ranging from 1 ('I disliked it very much') to 9 ('I liked it very much') and the optimal scale, ranging from 4 ('extremely low pineapple taste / sweet / crunchy') to +4 ('extremely high pineapple/ sweet / crunchy', for ideal intensity of flavor, sweetness and crispness of pineapple [15].

Using SAS software [16], the data obtained were statistically analyzed by analysis of variance (ANOVA) and mean test (Tukey), at 5\% level of probability for each group with the same type of almonds.

\section{RESULTS AND DISCUSSION}

Table 2 presents the averages awarded by consumers regarding sensory acceptance of bars made with almonds of chichá, complemented with pineapple peel. It may be observed that the attribute appearance showed no variation in the three formulations ( $p>0.05)$, whereas other attributes of the formulations evaluated differed $(p \leq 0.05)$. Formulation $\mathrm{B}$ obtained the highest score, regarding attributes such as color (7.6), texture (7.3) and overall impression (7.1); however, it did not differ significantly from formulation $\mathrm{C}$, whose score was: color (6.8), taste (6.9), texture (7.2) and overall impression (7.1). The formulation A received the lowest scores in all attributes evaluated without differing from formulation $\mathrm{B}$ for flavor and formulation $\mathrm{C}$ for color. Baixauli et al. [17], studying the effect of progressive resistant starch in similar baking products, found results close to the values found in the present study, for attributes such as appearance, texture and overall acceptability.
With sensory evaluation, it was observed that from the three different formulations of bars (A, B, C), made with almonds of chichá and complemented with pineapple peel, the results, based on all parameters, showed that formulations $\mathrm{B}$ and $\mathrm{C}$ had more acceptability than formulation $\mathrm{A}$.

Freitas and Moretti [18] evaluated three formulations of banana flavored-functional cereal bars, and they obtained lower scores for attributes such as appearance (4.0 to 6.0), color (5.3 to 6.6), texture (4.1 to 5.3), overall impression (4.7 to 6.1), however, concerning taste, the scores were higher (5.1 to 6.4) only to flavor in formulation A which reached 6.1. According to results found by Brito et al. [19], in a study of homemade cereal bars, the scores obtained for both appearance (4.2 to 6.6), and for color (0.9 to 3.4); therefore, the averages remained below the marks obtained for bars with almonds of chichá. As for the overall impression (6.1 to 6.9), the results were similar to those obtained for cereal bars made with almonds of chichá.

The average marks awarded for chichá cereal bars supplemented with pineapple peel, for the three formulations (A, $\mathrm{B}, \mathrm{C})$ are within the range of marks attributed to cereal bars made from albedo of passion fruit, according to Matsuura [20], referring to appearance parameters (6.7 to 7.5$)$, color (6.4 to 7.3$)$, taste (6.8 to 7.6$)$ and texture (6.3 to 7.1$)$. In relation to the overall impression (6.6 to 7.5$)$, only formulations $\mathrm{B}$ and $\mathrm{C}$ are within the score range.

The average values of marks awarded by consumers/assessors for sensory acceptance of bar formulation made with almonds of sapucaia, supplemented with pineapple

Table 3. Averages of Marks Awarded by Assessors for sensory acceptance of Bar Formulations Made with Almonds of sapucaia Supplemented with Pineapple Peel

\begin{tabular}{|c|c|c|c|c|c|}
\hline \multirow{2}{*}{ Formulation } & \multicolumn{5}{|c|}{ Sensory parameters $^{1}$} \\
\cline { 2 - 6 } & Appearance & Color & Flavor & Texture & Global impression \\
\hline \hline A & $6,9 \mathrm{a}$ & $6,9 \mathrm{a}$ & $7,0 \mathrm{a}$ & $7,1 \mathrm{a}$ \\
\hline $\mathrm{B}$ & $6,8 \mathrm{ab}$ & $6,9 \mathrm{a}$ & $6,9 \mathrm{a}$ & $7,2 \mathrm{a}$ & $6,6 \mathrm{a}$ \\
\hline C & $5,9 \mathrm{~b}$ & $5,8 \mathrm{~b}$ & $5,9 \mathrm{~b}$ & $6,2 \mathrm{~b}$ \\
\hline $\mathrm{CV}(\%)$ & 29,4 & 28,8 & 28,1 & 23,9 & 25,7 \\
\hline
\end{tabular}

${ }^{1}$ Averages and coefficient of variation. Averages with the same letter, in the same column, do not differ among them by Tukey test at $5 \%$ significance. Formulation A: added to $5 \mathrm{~g}$ of hydrogenated vegetable fat and 4 grams of pineapple peel powder. Formulation B: added to $4 \mathrm{~g}$ of hydrogenated vegetable fat and $5 \mathrm{grams}$ of pineapple peel powder. Formulation C: added to $3 \mathrm{~g}$ of hydrogenated vegetable fat and 6 grams of pineapple peel powder. 
peel, are described in Table 3. Among the attributes evaluated, only texture did not differ statistically in the three formulations, thus showing the same acceptance, independently on the concentration of ingredients added to obtain a different texture. Formulations A and B showed, respectively, the highest marks for the following parameters: color (6.9 and 6.9), taste (7.0 and 6.9) and overall impression (7.1 and 7.1), not differing, statistically, among them. Formulation $\mathrm{C}$, in its turn, presented the lowest scores for these attributes.

Regarding appearance, the formulation A (4g pineapple peel powder plus $5 \mathrm{~g}$ fat hydrogenated $/ 100 \mathrm{~g}$ ) has obtained the highest score, thus it was not different from formulation B that has a higher concentration of pineapple peel powder $(5 \mathrm{~g} / 100 \mathrm{~g})$, and lower hydrogenated fat content $(4 \mathrm{~g} / 100 \mathrm{~g})$ than formulation A. However, Formulation $\mathrm{A}$ is different from Formulation $\mathrm{C}$, which presents the highest concentration of pineapple peel powder $(6 \mathrm{~g} / 100 \mathrm{~g})$ and lower vegetal fat content $(3 \mathrm{~g} / 100 \mathrm{~g})$. These results show that the attribute appearance obtained lower scores, as the concentration of pineapple peel powder increased, therefore, reflecting negatively on the cereal bar appearance. This is, probably, due to the fact that the pineapple peel powder is more available to the aggregation of ingredients, and contributes to cause the darkening of the cereal bar.

Based on all parameters evaluated, it is observed, by sensory evaluation, that among the three cereal bar formulations made with almonds of sapucaia, supplemented with pineapple peel, those formulations A and B were more easily accepted than formulation $\mathrm{C}$.

The results obtained by Gutkoski et al. [21] for oat-based cereal bars with high food fiber content, for the attributes texture (7.4 to 7.6$)$, taste (6.9 to 7.7$)$, appearance (7.3 to 7.5 ) and overall impression (7.1 to 8.1), were close to the scores obtained for cereal bars made of sapucaia almonds, formulations $\mathrm{A}$ and $\mathrm{B}$, for the same sensory attributes.

Scores obtained for sensory acceptance, for the sapucaia bar, in formulations $\mathrm{A}$ and $\mathrm{B}$, were higher than those found by Freitas and Moretti [18] for the parameters appearance (4.0 to 6.0 ), color (5.3 to 6.6 ), flavor (5.1 to 6.4), texture (4.1 to 5.3) and overall impression (4.7 to 6.1) in functional cereal bars with high protein and vitamin content. Formulation C showed higher scores than those obtained by this author, only for texture and overall impression attributes.

The results obtained in acceptance test for cereal bars with amaranth, are similar to marks awarded to cereal bars made with almonds of sapucaia, in the formulations A and B [22].

The averages of marks obtained for cereal bars made with almonds from sapucaia, supplemented with pineapple peel, in formulations $\mathrm{A}$ and $\mathrm{B}$, are within the range of scores attributed to cereal bars with albedo of passion fruit [20], in regards to the parameters: appearance (6.7 to 7.5), color (6.4 to 7.3$)$, taste (6.8 to 7.6) and overall impression (6.6 to 7.5). For Formulation C, only texture (6.3 to 7.1$)$ was within the score range obtained by these authors.

Table 4 shows the averages of scores awarded by assessors for sensory acceptance of bar formulations made with almonds of gurguéia nut, supplemented with pineapple peel. Sensory evaluation showed no difference, between the three formulations, in any of the attributes evaluated. It was observed that, among the cereal bars made with the three different types of almonds, the bar made with gurguéia nut obtained the lowest scores, regarding all attributes tested, thus highlighting the low level of acceptance of cereal bars made with this type of almond.

The sensory evaluation enabled to verify that the three formulations of bars made with almonds of gurguéia nut, supplemented with pineapple peel, showed the same degree of acceptability by consumers.

Comparing the results obtained in this study with those obtained by Freitas and Moretti [18], who worked with cereal bars with high protein and vitamin content, the overall impression attribute (4.7 to 6.1) was close to the score found for cereal bars made with almonds from gurguéia nut (5.4 to 5.9).

The low level of acceptance of the cereal bar made with gurguéia nut is related, mainly, to its slightly bitter flavor and dark color, characteristics that were pointed out by the majority of consumers. They chose the taste and color as the least appreciated attribute. According to the hedonic scale, which measures the level of acceptance of a product by a given population, and which reports the pleasant and unpleasant sensations felt in the body [15, 20, 23-25], it is observed that the attributes appearance, color, flavor and overall impression, conferred to the cereal bars made with almonds from gurguéia nut, are in the range of indifference (I neither liked it, nor disliked it), on the other hand, texture was better scored, getting an average, which was equivalent to the interval 'I liked it a bit' (score 6) and 'I liked it moderately' (score 7).

Table 4. Average of Scores Awarded by Assessors, for sensory acceptance of Bar Formulations Made with Almonds of gurguéia Nut, Supplemented with Pineapple Peel

\begin{tabular}{|c|c|c|c|c|c|}
\hline \multirow{2}{*}{ Formulation } & \multicolumn{5}{|c|}{ Sensory parameters ${ }^{1}$} \\
\hline & Appearance & Color & Flavor & Texture & Global Impression \\
\hline B & $5,4 \mathrm{a}$ & $5,1 \mathrm{a}$ & $5,3 \mathrm{a}$ & $6,8 \mathrm{a}$ & $5,9 \mathrm{a}$ \\
\hline $\mathrm{C}$ & $5,2 \mathrm{a}$ & $5,0 \mathrm{a}$ & $4,9 \mathrm{a}$ & $6,5 \mathrm{a}$ & $5,4 \mathrm{a}$ \\
\hline A & $4,9 \mathrm{a}$ & $4,9 \mathrm{a}$ & $5,3 \mathrm{a}$ & $6,4 \mathrm{a}$ & $5,7 \mathrm{a}$ \\
\hline $\mathrm{CV}(\%)$ & 38,8 & 39,4 & 40,0 & 27,8 & 33,3 \\
\hline
\end{tabular}

${ }^{1}$ Averages and coefficient of variation. Averages with the same letter, in the same column, do not differ among them by the Tukey test, at $5 \%$ significance. Formulation A: addition of $5 \mathrm{~g}$ of hydrogenated vegetable fat and 4 grams of pineapple peel powder. Formulation B: addition of $4 \mathrm{~g}$ of hydrogenated vegetable fat and 5 grams of pineapple peel powder. Formulation $\mathrm{C}$ : addition of $3 \mathrm{~g}$ of hydrogenated vegetable fat and 6 grams of pineapple peel powder. 


\section{CONCLUSION}

The results of sensory analysis showed that almonds of chichá, sapucaia and gurguéia nut, as well as the residue and pineapple peel, may be used, successfully, to develop new formulations of cereal bars. Based on results regarding overall impression, the bars best accepted by the consumers were those of Formulation B (addition of $4 \mathrm{~g}$ of hydrogenated vegetable fat and 5 grams of pineapple peel powder $/ 100 \mathrm{~g}$ cereal bar), for the three kinds of nuts used. Cereal bars made with almonds of chichá and sapucaia, supplemented with pineapple peel were more accepted, in general, by consumers involved in the experiment, than the cereal bars made with almonds of gurguéia nut, supplemented with pineapple peel.

\section{ACKNOWLEDGEMENTS}

Our gratitude to FUNCAP for the financial support, and to the Federal University of Ceará for the infrastructure provided and scientific support.

\section{REFERENCES}

[1] Bower, JA, Whitten, R. Sensory characteristics and consumer linking for cereal bar snack foods. J Sensory Studies 2000; 15: 327345 .

[2] Palazzolo, G. Cereal bars: they're not just for breakfast anymore. Cereal Foods World 2003; 48: 70-72.

[3] Gomes, CR, Montenegro, FM. Current technology of the cereal bars 2006. Campinas: ITAL.

[4] Brinnehl, C. Raising the bar. Prepared Food 2005; 174: 31pp.

[5] Roberts Junior, WA.Trends Category Analysis: Bar none. Prepared Foods 2003. USA. Available at: http://www.preparedfoods.com/CDA/Archives?issue=65106. Accessed on: May 25, 2009.

[6] Ferreira, LG. Bars with functional properties of cereals targeted to women during menopause 2004. 99p. Dissertation (Master in Food Technology) - Faculty of Food Engineering, Federal University of Ceará, Fortaleza 2004.

[7] Esteller, MS, Yoshimoto, RMO, Amaral, RL, Lanne, SCS. Use of sugars in baked products. Food Sci Technol 2004; 4: 602 - 607.

[8] Araújo, ECE. Chichá (Sterculia striata St. Hill. Naud et): a new option for the national and international markets for walnuts. In: National Botanical Congress, 55, 2004, Viçosa, MG. Anais. Viçosa: SBB / UFV, CD-ROM.
[9] Vasques, AR, Bertol, SL, Valle, RCSC, Valle, JAB. Sensory evaluation and determination of shelf-life of dehydrated apples. Food Sci Technol 2006; 26: 759-765.

[10] Chitarra, MIF. Indexes physical, chemical and chemical. In: Chitarra, MIF. Post-harvest Fruit and Vegetables: Physiology and Handling 1999. Lavras: ESAL / FAEPE, 276-277.

[11] Timofiecsyk, FR, Pawlowsky, U. Minimization of waste in food industry: Rev Bull Center Food Process 2000; 18: 221-236.

[12] Queiroz, MB, Garcia, NHP. Evaluation of the sensory profile of almonds of roasted cocoa cupuaçu and using quantitative descriptive analysis. Bull Center Food Process 2000; 18: 249-266.

[13] Varnam, AH, Sutherland, JP. Beverages, technology, chemistry and microbiology 1997. Zaragoza: Acríbia, p. 487.

[14] Uchôa, AMA. After addition of food waste from the tropical fruit in the formulation of biscuits 2007. Fortaleza, 89p. Dissertation (Master in Food Technology), Faculty of Food Engineering, Federal University of Ceará, Fortaleza 2007.

[15] Dutcosky, SD. Sensory Analysis of Foods. 2nd Ed. Curitiba: Editor Champagnat, 2007; p. 239.

[16] SAS. Statistical Analyzer System. SAS user's guide, 2006; Version 9.1, Cary, NC: SAS Institute.

[17] Baixauli, R, Salvador, A, Martínez-Cervera, S, Fiszman, SM. Distinctive sensory features introduced by resistant starch in baked products. LWT - Food Sci Technol 2008; 20: 1-7.

[18] Freitas, DGC, Moretti, RH. Characterization and sensory evaluation of functional cereal bar, high protein and vitamin content. Food Sci Technol 2006; 26, 318-324.

[19] Brito, IP, Campos, JM, Souza, TFL, Wakiyama, C, Azevedo, GA. Preparation and comprehensive assessment of homemade cereal bar. Bull Center Food Process 2004; 22: 35-50.

[20] Matsuura, FCAU. Study of albedo of fruit and its use in the cereal bar 2005. 157p. Tese. (Doctor in Food Technology) - Faculty of Food Engineer, State University of Campinas, Campinas 2005.

[21] Gutkoski, LC, Bonamigo, JMA, Teixeira, MF, Pédo, I. Development of the cereal bars based on oats with high content of dietary fiber. Food Sci Technol 2007; 27: 355-363.

[22] Coelho, K. D. Development and evaluation of the acceptance of morning cereal bars and cereal-based amaranth (Amaranthus cruentus L.). 99p. Dissertation (Masters in Applied Human Nutrition) School of Public Health, University of São Paulo, São Paulo 2006.

[23] Torrezan, R, Ceccato, CM, Barretto, ACS, et al. Evaluation of the sensory profile of foods with soy orange flavor. Bull Center Food Process 2004; 22: 199-216.

[24] Meilgaard, M, Civille, GV, Carr, BT. Sensory evaluation techniques; $2^{\text {nd }}$ ed. Florida: CRC Press 1991; p. 354

[25] Stone, H, Sidel, JL. Sensory evaluation practices 1993. 2ed. London: Academic Press, 1993; p. 336.

(C) de Carvalho et al.; Licensee Bentham Open.

This is an open access article licensed under the terms of the Creative Commons Attribution Non-Commercial License (http://creativecommons.org/licenses/by-nc/3.0/) which permits unrestricted, non-commercial use, distribution and reproduction in any medium, provided the work is properly cited. 